\title{
Mining Economies: Inuit Business Development and Employment in the Eastern Subarctic
}

\author{
Anteneh Belayneh \\ Carleton University \\ Thierry Rodon \\ Université Laval \\ Stephan Schott \\ Carleton University
}

Abstract: The Raglan mine in Nunavik, in the province of Quebec, and Voisey's Bay mine in Nunatsiavut, in the province of Newfoundland and Labrador, are important drivers of economic development in their respective regions. Existing studies and data concerning the economic impacts of extractive industries are concentrated on the national or regional impacts, and do not assess the impacts on business and human development at the local and community level. The article analyzes the impacts of the Raglan Mine and the Voisey's Bay Mine on business development and employment in Nunavik and Nunatsiavut respectively. The article presents the design, methodology, and results of a three-year study in which focus groups and surveys were conducted with business owners. We report on the views and experiences of business owners with respect to how mining has impacted local business development. We evaluate some community employment trends, identify policy insights, and recommend future research directions to improve the utilization of mining benefits by local Indigenous communities and Indigenous governments.

The Northern Review 47 (2018): 59-78 


\section{Introduction}

The impacts of extractive industries are multi-fold, and include the environmental, social, and economic. The rationale underpinning the mining of non-renewable resources is the purported economic benefits they bring, both generally and for the local communities they closely impact. Extractive industries are often expected to bring economic benefits to local communities through the provision of higher wages, training, growth of entrepreneurial initiatives, and transfer payments and royalties. It has been argued that, in the long term, the economic benefits of extractive industries promote economic diversification and inter-sectoral linkages in other areas of the local economy (Eggert, 2001; Fleming \& Measham, 2015).

The validity of these claims is contested. Studies have claimed that non-renewable resource exploitation can also lead to an increase in income inequality within communities; may capture critical human, social, and cultural capital; and has the potential to leave a harmful legacy on the land (Sandlos \& Keeling, 2012; United Nations Department of Economic and Social Affairs, 2007). In the case of communities in the Canadian Subarctic, mining-induced changes to territories, lifestyles, and livelihoods can present adverse effects for individuals, households, and communities affected by these developments, and can threaten to disrupt the delicate balance and tight interrelations that are characteristic of northern mixed economies (Bernauer, Kissling-Näf, \& Knoepfel, 2000; Rodon \& Schott, 2014).

Indeed, the economic impact of mining on local communities is an unsettled question. On the one hand, mining may increase the budgets of local communities, leading to increased spending on infrastructure (Land, Chuhan-Pole, \& Aragona, 2015). On the other hand, the presence of mining has led to competition among different industries for local labour and an increase in the level of inequality due to the higher incomes from mining jobs (Rolfe, Gregg, Ivanova, Lawrence, \& Rynne, 2011). Some studies have argued that the economic benefits from mining accrue on a regional scale as opposed to a local scale (Ejdemo, 2013). Huskey and Southcott (2016) applied a staples framework to the experience with mining in the Yukon. They identified forward, backward, final demand, and fiscal linkages. For the most recent mining boom period from 2000 to 2012, they found that although Yukon resource revenues only made up 10\% of the total economic rent, there were substantial other linkages, particularly 
backward linkages in the form of local spending by mining companies (Huskey \& Southcott, 2016). Their estimation was on a regional scale and it is not clear whether communities and business sectors received any of the benefits. A more detailed look at the types of linkages, and to what extent they are experienced at different stages of the mining process, are important issues to be further explored.

This unsettled question about whether mining leads to economic benefits-especially for local communities - was the motivation behind our research project "Mining Economies, Mining Families: Extractive Industries and Human Development in the Eastern Subarctic." ${ }^{1}$

The importance of education, training, and skills development in the Canadian Arctic is often stressed when discussing the economic impacts of mining and other extractive industries (Zhang \& Swanson, 2014). In the context of small communities, whether there is enough capacity to take advantage of the economic opportunities is an important consideration. Scholars have highlighted the importance of capacity building-the purposeful implementation of measures to address problems and increase the stock of skills within a community to benefit from economic opportunities - as crucial in the Canadian North (Swanson \& Zhang, 2015; Zhang \& Swanson, 2014).

Assessing the economic impacts of mining in the Canadian Subarctic raises additional questions regarding the participation of Indigenous peoples in economic development and whether a fair share of these economic benefits goes to these communities. Economic development can ensure that residents in the region receive a share of the wealth extracted from their lands and enjoy opportunities similar to their counterparts in the rest of Canada (Swanson \& Zhang, 2015). While there are unanswered questions about the impact of extractive industries on local economic development, the impacts on business development are even more under-researched (Kemp, 2010). This research project has focused on local businesses, human development, and local employment, and is assessing whether the presence of major mining projects impacts development. The focus on business was first due to the profound level of under-research concerning local small-business development around mining (Kemp, 2010), and second because of regional Inuit governments' interest to explore this issue in more detail at a community level. Another motivation was assessing to what extent these economic benefits trickled down to local businesses.

Finally, this project was comparative. The economic impacts of the Raglan Mine, in Nunavik, Quebec, especially on local business 
development, were compared to the impacts of the Voisey's Bay Mine in Nunatsiavut, Labrador. The extent to which each region benefited from these mining operations is unclear-and it is also unclear if the economic development outcomes differ between the two regions. Both are major mining operations with a significant lifetime. The Raglan Mine began operating in 1998 and is currently operated by Glencore. Five additional mines are expected to become operational and extend the lifespan of this mining project to 2041. The Voisey's Bay Mine started operations in 2005 and the mine is expected to last until 2032, largely due to the underground expansion of the mine expected to be completed by 2021. The institutional context of the two regions differs significantly, and the project aims to determine whether these differences lead to differing development outcomes. Whether these institutional differences led to any significant difference in how local Inuit businesses developed and derived economic benefits from mining was an important question driving the comparative approach.

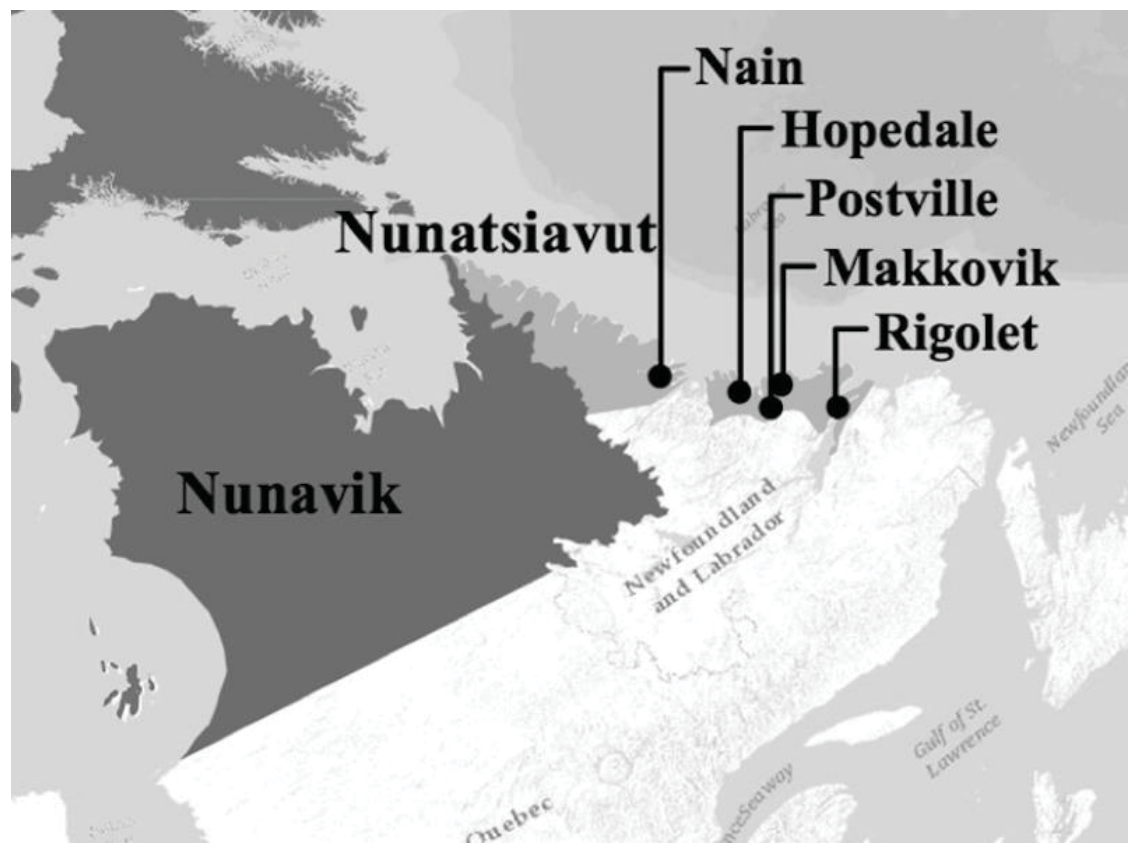

Figure 1. Map of Nunavik, Quebec, and Nunatsiavut, Newfoundland and Labrador (Source: Government of Canada, 2017) 
The political organizations of the two regions differ in a myriad of ways. The Nunatsiavut Government is an Inuit regional government with several areas of jurisdiction over Inuit communities in the province of Newfoundland and Labrador. Five communities also have their own local Inuit Community Government-Nain, Hopedale, Postville, Makkovik, and Rigolet.

The Kativik Regional Government (KRG) is the public administrative body for most of the Nunavik region in northern Quebec. Makivik Corporation is the entity with the mandate, under the James Bay and Northern Quebec Agreement (JBNQA), to represent the Inuit of Nunavik in their relations with the province of Quebec and the Canadian federal government, and to address issues pertaining to the JBNQA. Makivik was the first Inuit economic development corporation in Canada (Wilson \& Alcantara, 2012). In addition, landholding corporations in Nunavik play a lead role in the administration, protection, and use of the category I and II lands that were specified in the JBNQA. The institutional structure of the Nunavik region has both public and ethnic governance bodies (Wilson \& Alcantara, 2012). The public governance bodies are the KRG, the Nunavik Regional Board of Health and Social Services (NRBHSS), and the Kativik School Board (KSB). Makivik, by contrast, is an ethnic based, private, notfor-profit corporation owned by the Nunvaik Inuit.

The differences between Nunatsiavut, in Labrador, and Nunavik, in Quebec, extend to their demographic profiles, with 2,500 Inuit living in Nunatsiavut, whereas there are 12,000 inhabitants in Nunavik and $98 \%$ are Inuit (Government of Canada, 2016a). Inuktitut is also much more prevalent in Nunavik with $98 \%$ of the population speaking it (Government of Canada, 2016b), while only 11\% of residents in Nunatsiavut speak Inuktitut (Government of Canada, 2016b). There is also an important difference in educational attainment, with $33 \%$ of Nunatsiavut Inuit having a certificate, diploma, or degree from a trade school, college, or university (Statistics Canada, 2016a), while this figure is only $24 \%$ in Nunavik (Statistics Canada, 2016b).

Along with the institutional differences, employment practices at the respective mine sites has differed significantly. In August 2017, Inuit employment at the Raglan mine peaked at 189, representing around $20 \%$ of the total workforce; a very small proportion of those Inuit employees originated from the closest communities-Salluit and Kangiqsujuaq (Rodon \& Levesque, 2015). At the Voisey's Bay Mine, forty-five Inuit employees, representing $42 \%$ of the workforce, were from Nunatsiavut and Happy Valley-Goose Bay (21\% from Happy Valley-Goose Bay 
alone). Understanding the differences in these employment figures and identifying potential causes was another motivating factor in our analysis of the economic impacts of mining in these two regions.

In this article we report on the views and experiences of business owners in both regions, with respect to how mining has impacted local business development. We evaluate some community employment trends and identify policy insights and future research directions in order to improve the utilization of mining benefits by local Indigenous communities and governments.

\section{Methodology}

To determine the impacts of mining on the economic and business development of communities in Nunavik and Nunatsiavut we first approached business owners in both regions and conducted four focus groups. The focus group sessions informed the design of a comprehensive business survey. The collaboration of local partners-Makivik Corporation in Nunavik and the economic development division of the Nunatsiavut government-were instrumental in the identification of participants for both the focus groups and surveys. The focus groups, in October 2015, preceded the survey design process and were conducted with selected businesses from both regions. Three of the focus group sessions were conducted in Kuujjuaq, Nunavik, and one of the sessions was conducted in Salluit, Nunavik. The business survey was conducted between May 2016 and February 2017 in both regions. We presented our findings to regional partners and interested businesses in Fall 2017, including followup questions with specific businesses and a discussion of potential policy and process implications and changes. On the employment and human development side of the project we analyzed employment, revenue, income, and training data from mining companies and Statistics Canada. Our final step in the project was offering several recommendations and policy insights for more beneficial involvement of Inuit-owned businesses with the mining industry, and more meaningful and substantial involvement of Inuit employees in employment, skills acquisition, and training in the mining companies (such as Glencore, Vale, and Canadian Royalties) and in Inuit-owned local businesses. 


\section{Focus Groups}

Originally, we planned to conduct separate focus groups in Nunatsiavut, Happy Valley-Goose Bay, Salluit/Kangiqsujuaq, and Kuujjuaq. Both the Makivik Corporation in Nunavik and the Nunatsiavut Government suggested, however, that we use this opportunity to bring together business and government representatives from both regions to exchange experiences with the mining industry and to network. We therefore decided to bring in business and government officials from Nunatsiavut and Happy Valley-Goose Bay to Kuujjuaq, Nunavik in a specially chartered airplane. This was the first time business leaders and government officials from both regions had met to discuss Inuit business development and to exchange experiences, ideas, and business cards. The focus group sessions were held in Kuujjuaq, Quebec on October 26-27, 2015. The focus group questions were designed to establish the views of business owners with respect to mining, and whether mining makes a positive contribution to business and economic development. In addition, a review of the literature on mining-induced development had highlighted the potential for the mining sector to compete with other sectors for labour, where other sectors were unable to offer competitive wages. The study aimed to establish if this phenomenon was present in any of the communities where the businesses were located. In addition, we asked businesses if there was a significant difference in benefits and development during different stages of a mine's life cycle.

Focus groups were partitioned by region and type of community in order to separate participants in regional hubs from those who may have experienced local impacts in small communities closer to the mine. Thus, business owners from Happy Valley-Goose Bay were separated from Nain and Rigolet businesses, while those from Kuujjuaq were separated from Salluit and Kangiqsujuaq ${ }^{2}$ business owners. An important claim in the literature on mining-induced benefits is that benefits are captured regionally as opposed to locally (Ejdemo, 2013). Separating the participants based on their proximity to the mine ensured that different voices and experiences were heard and separately recorded.

Focus groups with participants from Nunavik and Nunatsiavut were conducted on separate days to ensure that differing experiences were easily identified. At the end of these focus group sessions, participants from both regions were brought together to discuss their concerns and successes. This process also allowed businesses that do not often communicate to network and share experiences. 
With respect to the benefits of mining, focus group participants stressed that different stages of mining bring forth differing level of benefits and challenges. These participants also highlighted concerns regarding the leakage of economic benefits from communities that are closer to the mine, compared to those in regional hubs. As most of the mining literature has not been contextualized to the institutional arrangements of the Canadian Subarctic, these sessions helped identify impacts and challenges endemic to the region. These sessions also informed the design of a survey that was administered to businesses throughout both regions, and helped tailor survey questions to the context of Nunavik and Nunatsiavut. In addition, information that was not identified in the literature was incorporated into the survey design.

\section{Business Survey Design and Administration}

After completing the focus groups, a business survey incorporating the findings was designed. This business survey comprised sixty questions. It was designed to identify the types of businesses and differentiate the impacts of mining on business activity during the different stages of mine development. Furthermore, questions addressed the extent to which businesses depended on mining-related activities for their revenue; the formation of partnerships within and outside of their region; barriers to business development; satisfaction with the Impact Benefit Agreement (IBA) and its impacts; employment at Inuit businesses; competition for labour; competition with other companies within and outside the region; and training and support programs. Initially, the survey was piloted on a small scale in both Nunavik and Nunatsiavut. In April 2016, the survey was piloted at the Kuujjuaq mining workshop and a month later with a number of businesses at their premises in both Nain and Happy ValleyGoose Bay.

Initial responses to the survey were very positive, and business owners indicated their desire to be heard and to share their experiences with the researchers and the regional collaborators (the Nunatsiavut government and Makivik Corporation). Several businesses expressed a belief they were neglected in research involving mining impacts, and were generally relieved about a survey that specifically dealt with their experiences and concerns. Business owners were encouraged that their concerns were being studied and considered, and were quite pleased to engage with the research team. Business owners who had participated in the initial focus group sessions were happy that the project was advancing and were

happy to participate in an individual setting. The piloted surveys took 
about ninety minutes to conduct. Members of the research team travelled to both regions to pilot the surveys and both Makivik and the Nunatsiavut government helped identify potential participants.

Once surveys were piloted, Inuit researchers from both Nunavik and Nunatsiavut were identified, hired, and trained to administer the survey. All ninety-six surveys were conducted in person with the help of these local research assistants who were also instrumental in contacting participants. Thirty-eight of the surveys were conducted in Nunavik, in Salluit, Kangiqsujuaq, and Kuujjuaq, and fifty-eight surveys were conducted in the five communities of Nunatsiavut (Nain, Rigolet, Postville, Makkavik, and Hopedale), and in Happy Valley-Goose Bay, and Western Labrador. The questions were loaded to iPads through the iSurvey program, which allowed research assistants to conduct the survey remotely and upload their results when they regained an internet connection. All uploaded surveys were received on the iSurvey account that was established by the research team for this purpose.

\section{Results and Findings}

In addition to the survey, focus group results also informed the study of the issues facing the Canadian Subarctic with respect to mining. The following section will briefly outline and discuss the findings garnered from the surveys and focus groups.

\section{Exploration Phase}

Through our literature review, we had identified the possibility that economic impacts would differ between the construction and operation phases. This possible distinction was a major theme before the focus groups. During the focus group sessions, participants highlighted the importance of the exploration phase. Businesses stated that their revenue and level of activity peaked during this phase. Initially, participants from Nunavik indicated that their involvement with the mining industry had declined greatly since the exploration phase. Their experiences were confirmed by participants from both regions of Nunatsiavut. The importance of the exploration phase was incorporated into the business survey. Survey questions were designed to discover whether businesses were involved with a mine during each of the mining stages, and whether this involvement changed over time.

Interestingly, the survey results did not support most of the focus group participants' statements, which had conveyed that the exploration 
phase was the most active phase. In Nunavik, the operation phase was the most active for businesses engaged in mining or exploration activities ( $45 \%$ of those surveyed), with $32 \%$ indicating the exploration phase was most active. In Nunatsiavut, only $12 \%$ of the businesses indicated that the exploration phase was the most active, while the majority (56\%) claimed the operation phase was the most active for their business.

\section{Governance Structures}

Focus group sessions with participants from Kuujjuaq brought forth concerns from business owners regarding the relationship between their businesses and the Quebec provincial government. These concerns were generally about a lack of communication and a lack of procurement strategy that could allow local businesses to procure contracts. These concerns were not present with the Nunatsiavut businesses, however, whose discussions regarding government centred almost exclusively on the Nunatsiavut regional government, not the provincial government of Newfoundland and Labrador. The survey was designed to address whether these businesses had comments regarding the role of government, either provincial or regional. We have hypothesized that the presence of a regionally elected government in Nunatsiavut would lead to all government queries and concerns being directed to this government. In contrast, the institutional diversity in Nunavik could result in conflicts, administrative overlaps, and coordination problems between the multiple institutions, and potentially a larger role for the provincial government.

\section{Mining Benefits Framework}

Ejdemo (2013) identified three distinct types of benefits that are derived from extractive industries. The study concluded that mining benefits can be direct, indirect, or induced (Ejdemo, 2013). Direct benefits consist of employment opportunities generated at the mine, while indirect benefits incorporate employment opportunities that are generated in supplying the mine (Ejdemo, 2013). Induced benefits are derived from the consumption surrounding mining development and the employment opportunities that are sustained by this consumption (Ejdemo, 2013). Ejdemo (2013) developed these definitions to assess if, and to what extent, local communities benefited from mining activities in northern Scandinavia. Much of the wealth generated in northern Canada and Scandinavia is transferred out of the regions (Swanson \& Zhang, 2015). In both regions, the endowment of natural resources does not necessarily 
guarantee prosperity due to the leakage of a large portion of the benefits from extractive industries (Swanson \& Zhang, 2015).

Given these similarities between northern Scandinavia and the Canadian Arctic, and the fact that Ejdemo's work focuses on mining benefits at the local and regional scale, this study developed a mining benefits framework linking Ejdemo's definitions with the different stages of mining at Raglan and Voisey's Bay. Using these definitions, we developed a framework (Belayneh, Rodon, \& Schott, 2017) linking these types of benefits with the stage of mining development. Our framework was developed after combining elements of the literature on economic benefits of mining with the responses of participants in the focus group sessions.

This framework hypothesizes that the direct benefits from miningi.e., employment opportunities at a mine-accrue mostly during the construction and operational phases when there is greater activity at the mine. In addition, these benefits would most likely accrue to individuals working at the mine as opposed to local or regional businesses. Indirect benefits would accrue to businesses who supply labour or other services to the mine during the construction or operation phases. During the exploration phase, where there is little activity at a mine site, indirect benefits can accrue to businesses who provide labour or other services for exploration purposes. The framework proposes that induced benefits would peak during the exploration phase. During this phase, there can be a lot of activity in communities close to a mine and this activity can lead to consumption of local goods and services. Once a mine progresses into the construction or operational phase, the fly-in fly-out schedule would limit the number of employees who traverse through these communities and the consumption of services within them.

The business survey will either confirm or dispel the relationships between the stages of mining development and the type of benefits that accrue to businesses and employees. While the validity of this framework in the context of Nunavik and Nunatsiavut is yet to be confirmed and validated in presentations to regional partners and businesses from different communities, the survey has produced several notable findings to date. Further details about the mining benefits framework, and other themes that emerged from the focus group discussions, are presented in Belayneh, Rodon, \& Schott (2017). The latter paper ties each stage of mining development with a benefit from mining (direct, indirect, induced). 
Quantitative Results: Business Environment, Type of Business by Region, and Employment Dynamics

The quantitative data produced by the survey illustrates some sharp distinctions in the business environments of Nunavik and Nunatsiavut. For example, the proportion of businesses in the Inuit business registry is significantly different (Figure 2). Only $48 \%$ of businesses surveyed in Nunavik indicated they were in the Makivik business registry (the Nunavik Inuit Enterprise Directory). There are multiple business registries in Nunavik, and Makivik is currently reviewing the qualification criteria for an Inuit business. One significant similarity between the two regions was the proportion of businesses that had partnerships or joint ventures. In Nunatsiavut, $40 \%$ of businesses had such an arrangement, and in Nunavik the number was $42 \%$.

Most of the businesses surveyed in Nunavik are incorporated (64\%), but the proportion of sole proprietorships was only $8 \%$. Incorporated businesses were the most prevalent business structure in Nunatsiavut $(42 \%)$, but the proportion of sole proprietorships was quite significant as well (33\%). Both regions exhibited similar levels of Inuit ownership. In Nunavik, $58 \%$ of businesses surveyed were $100 \%$ Inuit owned, with a similar Figure of $60 \%$ in Nunatsiavut (Figure 3).

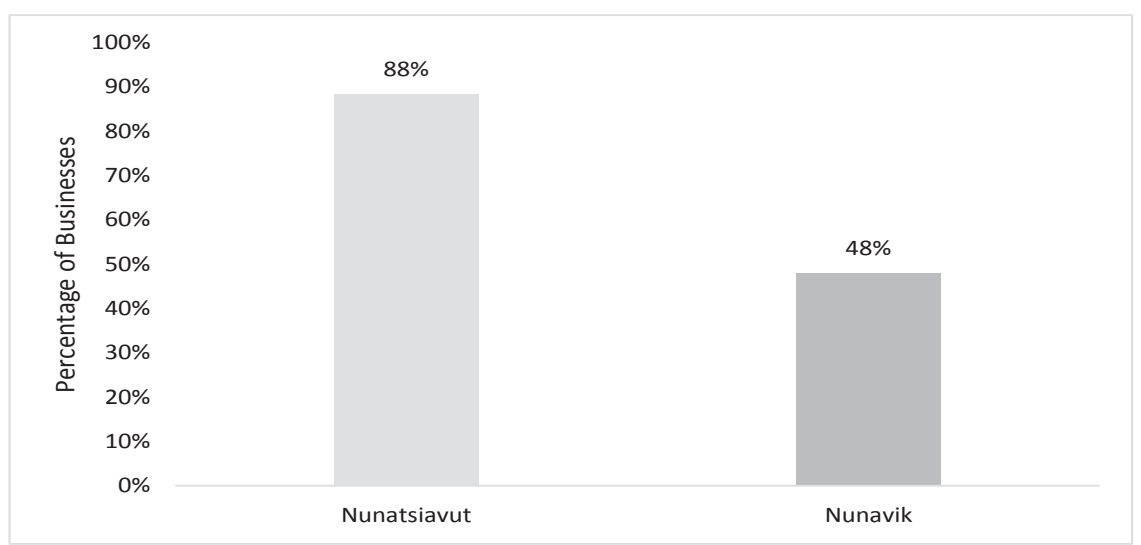

Figure 2. Proportion of total businesses present in the Inuit business registry 
The surveyed businesses exhibited a low level of specialization within the mining sector. Businesses participated in a variety of sectors in order to procure contracts from the mines and from other opportunities. Figure 4 shows the dominance of the service sector, especially in Nunavik.

When participants were asked about their business sector, they often listed several sectors (Figure 4). This might be evidence that businesses need to adjust from one mining stage to another in order to stay in business, which might result in less specialization and possibly more partnerships and joint ventures with partners from southern Canada. Validating these surveyed results in workshops with businesses, and further analysis of the survey data, will help to answer these questions. A lack of specialization undoubtedly could diminish the revenue and profit share of Inuit businesses in mining-related business opportunities because of a larger dependence on business partners from southern Canada.

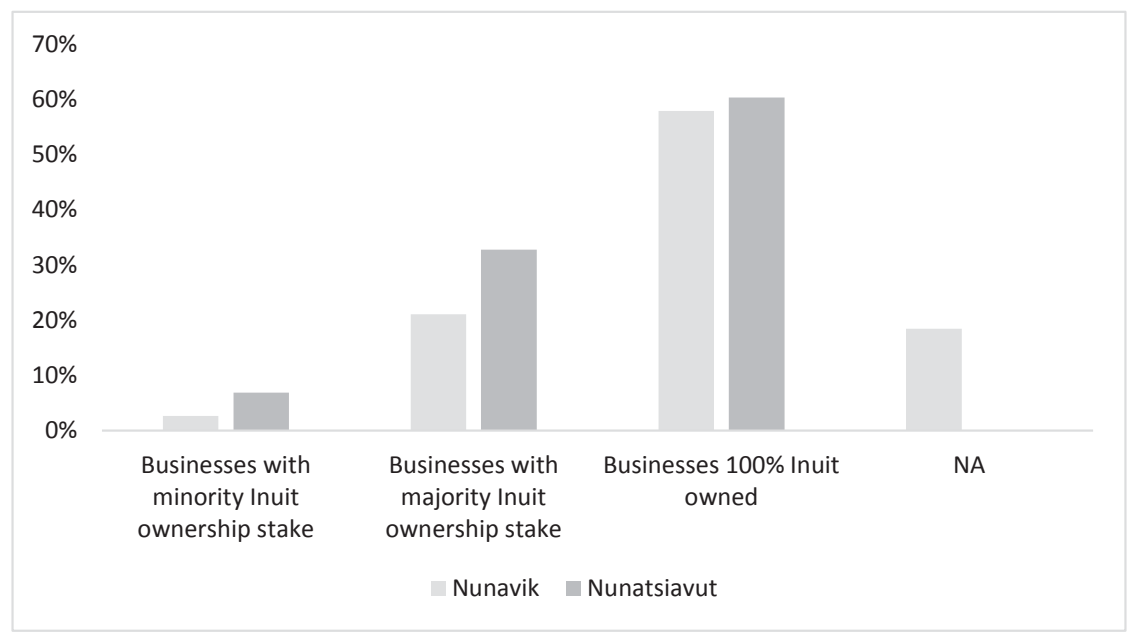

Figure 3. The level of Inuit ownership in surveyed businesses 


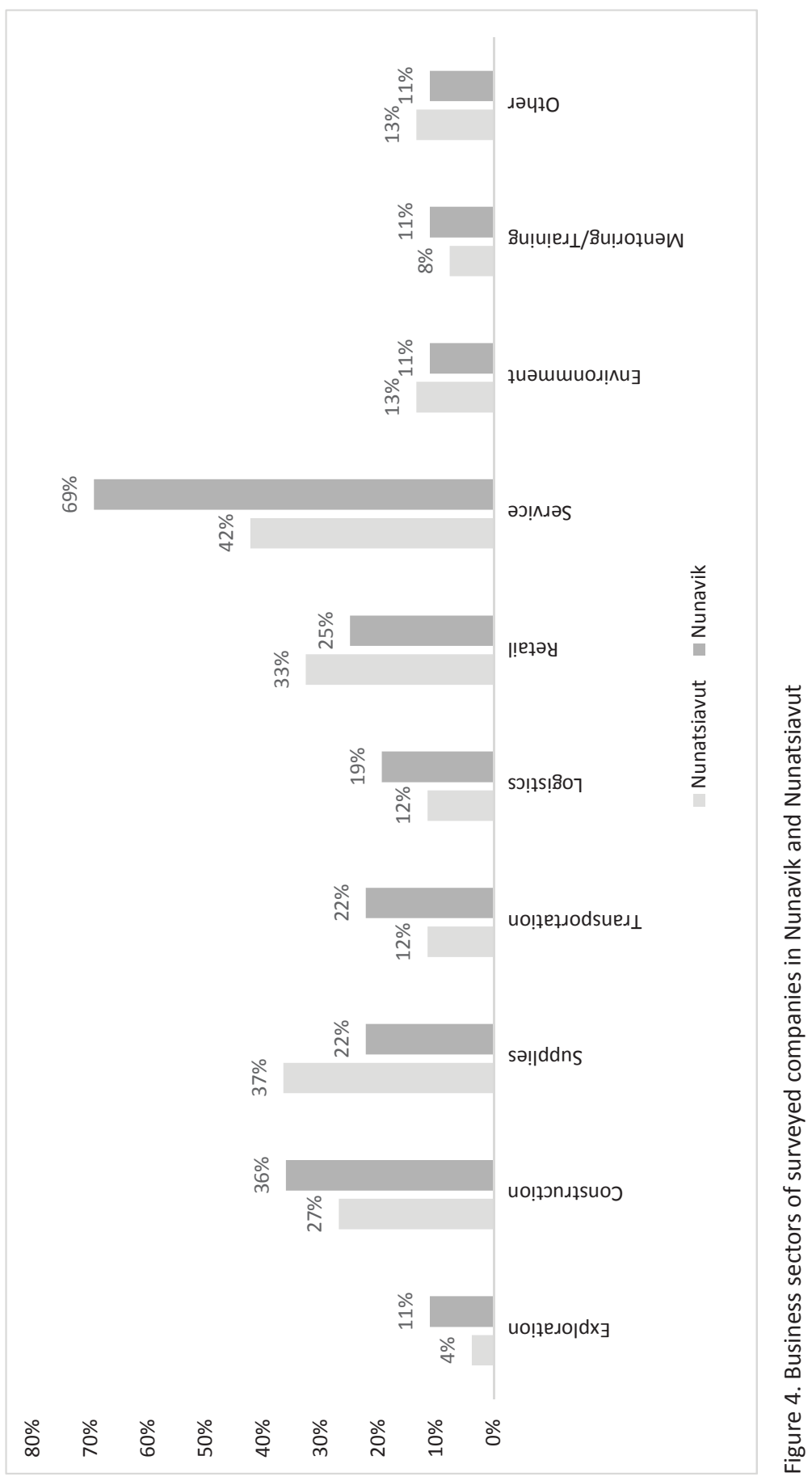

72

The Northern Review 47 | 2018 
Policy Insights

Focus group sessions indicated that some business owners, especially in Nunavik, felt the provincial government could do more to aid them in the procurement of contracts. Whether this viewpoint was shared across all businesses in both regions is subject to further qualitative analysis from the survey results. In addition, there is quite a discussion about the definition of an Inuit business. Is it merely $51 \%$ of Inuit ownership that determines an Inuit business (as is the case in Nunavik)? Or should Inuit partners be actively involved in the operation of the partnership or joint venture, and should there also be stipulations about Inuit employment and the location of the business (as, for example, in the Inuvialuit Settlement Region)? There is a rich literature on Indigenous entrepreneurship in the Canadian context. One perspective conceptualizes Indigenous entrepreneurship as the entrepreneurship of an Indigenous person or persons (Zhang \& Swanson, 2014). Another perspective distinguishes Indigenous entrepreneurship from entreprenership in general-due to the location of the business, the form of the business, or the ultimate objective of the enterprise (Zhang \& Swanson, 2014). Indeed, Indigenous entrepreneurship is conceptualized as a form of social entrepreneurship where enterprises emphasize community and are seen as an essential component of sustainable development. The definition of Inuit ownership affects business development, partnerships, and specialization. It is, therefore, essential to create the right criteria for an Inuit business in order to give preferential treatment to local Inuit companies in the allocation of mining contracts and business opportunities, and to spur local sustainable economic development.

One factor that differentiates Nunavik and Nunatsiavut with respect to mining is the existence of a mining policy for Nunavik (Makivik Corporation, 2014). The objectives of Nunavik's mining policy are to maximize the social and economic benefits of mining for Nunavik's Inuit population while minimizing the negative social and environmental impacts, and to build a relationship of trust among stakeholders by establishing open dialogue. On the issue of maximizing economic benefits, the mining policy specifies several principles including preferential hiring of Nunavik Inuit, building training capacity, and strengthening education levels and pre-employment processes. This is supposed to be a joint effort by mining companies, KRG, the Kativik School Board, and the Quebec government. In addition, mining companies must establish training and hiring programs for Nunavik Inuit. 
Nunavik Inuit businesses must obtain preferential contracting for the supply of goods and services at all stages of exploration, development, operation, and restoration phases, and tasks and contracts should be broken down as much as possible to allow local entrepreneurs to perform the work. Although it does not specify specific targets or how to implement many of the recommendations, Nunavik's mining policy provides a guideline and vision for mining companies and various institutions in Nunavik to collaborate. Nunatsiavut, on the contrary, does not have a mining policy. By assessing the economic impacts of the Voisey's Bay mine, and the impacts on the business community specifically, this study can help to inform the development of a comprehensive mining policy for Nunatsiavut, and provide inputs for the potential refinement of Nunavik's current mining policy.

\section{Looking Ahead: Future Research Directions}

The overall objective of this project was to assess the impacts that mining has on local economic and business development. The extent to which businesses rely on mining for their revenues and the importance of each stage of mining development will be determined after completion of survey analysis. This project will also shed some light on the role of specialization. It appears businesses have exhibited a low level of specialization, and they pursue contracts and opportunities in a variety of sectors. Whether this practice is to the detriment of those companies that do specialize will be assessed and this will inform business practices in the regions.

The legacy of the Impact Benefit Agreements and the perceptions that business owners have regarding these agreements will also be brought to light. These IBAs are a specific form of social licence where mining corporations and communities enter into a bilateral, voluntary agreement to achieve a more sustainable mining development that has an appropriate level of consultation and adequate provision of benefits and compensation (Koivurova et al., 2015). This project will examine the challenges and opportunities of businesses and will inform the drafting of further IBAs in these regions, as well as in other regions in the Canadian North. As indicated during the survey process, business owners were very pleased to offer their perspective and give voice to the challenges they face in their daily operations. This project will give regional governments an appreciation of these concerns and an opportunity to address them with future projects. It will also assess the level of familiarity the business community has with respect to the existing IBAs, and how satisfied they are with the realization of benefits and the implementation of the IBA. 
This project will also determine whether there is a role for the provincial government and what that role may entail in the promotion of business development. Whether the differing institutional arrangements between the two regions provide different avenues for provincial involvement will be assessed.

The results of this study - both the focus group and survey resultsneed to be compared to the objectives and stipulations in the IBAs to assess whether the goals of these agreements are met and whether sufficient benefits from mining activities are accruing to Inuit businesses. One concern expressed by focus group and survey participants is the leakage of benefits outside of local communities and even outside of the selfgovernance regions. In the context of mining, benefits leakage can mean several things. Participants referred to the leakage of economic benefits, such as the presence of training courses in regional hubs rather than local communities, or the fact that mining wages are spent on goods and services originating outside of the community. Leakage also refers to the migration of human capital and social capital from small communities to larger regional hubs that train employees and which are then used as a base for fly-in fly-out mining jobs. Participants had expressed that community residents migrated due to housing issues, in pursuit of training to gain employment and to have access to more goods and services. We need to assess the exact reasons for migration and how smaller communities can become more attractive centres for skills acquisition, training, mobile labour, and entrepreneurship. In addition, we need to further examine the most beneficial revenue sharing arrangements for local governments and communities. Here a comprehensive examination around the world could enlighten communities and capacity-constrained regional Indigenous governments for their negotiations with multinational companies that operate worldwide with often quite different agreements and conditions for revenue sharing, capacity building, and ensuring other local benefits. Finally, Indigenous communities and regional governments must decide how to distribute and reinvest resource revenues from mining operations that operate for a limited time. This is both a political as well as a financial decision. It should lead to some investments for future generations that further diversify the economy and create human capital and capacity without sacrificing social capital, traditional knowledge, cultural values, and a sense of belonging. 


\section{Conclusion}

Mining will continue to play a major role in northern communities in the future due to a large abundance of non-renewable resources of all types. Particularly with the transition to a low-carbon economy, we will require significant increases in mining copper, cobalt, rare earth metals, and other minerals that are abundant all over Canada's North. To get the most out of mining activities for northerners and their communities, we need to better understand what the potential economic benefits are and how they can be maximized. Our understanding of the dynamics of mining activities, local business creation and development, as well as household well-being and the impacts on subsistence harvesting, is very limited. We can no longer assume that the economic impacts of mining are always beneficial for all communities. It might lead to leakage, out-migration, and the loss of valuable labour and local businesses. The distribution of mining revenues and benefits matters for relative economic well-being and for potential political conflicts between individual communities and the governments and organizations that represent them.

Research needs to carefully examine how to improve benefits from mining, increase the access of local Indigenous businesses to mining contracts, and ensure local, and particularly Indigenous, people receive good training and have access to meaningful jobs with transferable skills outside of the mining sector. In addition, more meaningful and lasting local employment in the mining sector and in local businesses connected to the mining industry need to be created. Finally, benefits from mining need to be justly distributed and well invested to avoid a local regional resource curse that could create more harm than good.

We have made significant progress since the James Bay and Northern Quebec agreement and later land claims agreements. Now is the time to build on these achievements and to ensure that potential benefits are carefully evaluated and realized within the regions and by the communities that are most affected by mining activities.

\section{Acknowledgements}

This project was funded through an ArcticNet, Tri-Council grant. We would also like to acknowledge our partnership with Resources and Sustainable Development in the Arctic network (ReSDA). This project participated in the annual ReSDA workshop in 2015, 2016, and 2017 and has benefited from the sessions and discussions at these workshops. 


\section{Authors}

Anteneh Belayneh is a doctoral candidate at the School of Public Policy and Administration, Carleton University, Ottawa.

Stephan Schott is associate professor at the School of Public Policy and Administration, Carleton University, Ottawa.

Thierry Rodon is professor of political science at Université Laval, Québec City.

\section{Notes}

1. The project is supported by funding from Arctic Net (April 1, 2015-March 31,2018 ) and the Nunatsiavut Government, and with the support of Makivik Corporation.

2. The focus group session for Salluit and Kangiqsujuaq was conducted in Salluit.

\section{References}

Belayneh, A., Rodon, T., \& Schott, S. (2017). Inuit business views of the experiences with the mining sector in Canada's Eastern Sub-Arctic: Setting an agenda for research. Unpublished Working Paper.

Bernauer, T., Kissling-Näf, I., \& Knoepfel, P. (2000). Institutionalized management of scarce resources: Introduction and overview. Swiss Political Science Review, 6(1), 5-8. https://doi.org/10.1002/j.1662-6370.2000.tb00283.x

Eggert, R. G. (2001). Mining and economic sustainability: National economies and local communities. A Study Prepared for the Mining, Minerals, and Sustainable Development Project, Colorado School of Mines.

Ejdemo, T. (2013). Mineral development and regional employment effects in northern Sweden: A scenario-based assessment. Mineral Economics, 25(2), 55-63. https://doi.org/10.1007/s13563-012-0023-z

Fleming, D. A., \& Measham, T. G. (2015). Local economic impacts of an unconventional energy boom: The coal seam gas industry in Australia. Australian Journal of Agricultural and Resource Economics, 59(1), 78-94. https:// doi.org/10.1111/1467-8489.12043

Government of Canada. (2017). Inuit relations secretriat. Retrieved from http:// www.aadnc-aandc.gc.ca/Map/irs/mp/index-en.html

Government of Canada, S. C. (2016a, February 29). Inuit: Fact sheet for Nunatsiavut. Retrieved from http://www.statcan.gc.ca/pub/89-656-x/89-656-x2016015-eng. htm

Government of Canada, S. C. (2016b, February 29). Inuit: Fact Sheet for Nunavik. Retrieved from http://www.statcan.gc.ca/pub/89-656-x/89-656-x2016016-eng. htm 
Huskey, L., \& Southcott, C. (2016). “That's where my money goes": Resource production and financial flows in the Yukon economy. The Polar Journal, 6(1), 11-29. https://doi.org/10.1080/2154896X.2016.1171002

Kemp, D. (2010). Mining and community development: Problems and possibilities of local-level practice. Community Development Journal, 45(2), 198-218. https:// doi.org/10.1093/cdj/bsp006

Koivurova, T., Buanes, A., Riabova, L., Didyk, V., Ejdemo, T., Poelzer, G., ... Lesser, P. (2015). "Social license to operate": A relevant term in Northern European mining? Polar Geography, 38(3), 194-227. https://doi.org/10.1080/1 088937X.2015.1056859

Land, B. C., Chuhan-Pole, P., \&Aragona, F. M. (2015). The local economic impacts of resource abundance:Whathavewelearned?(No.WPS7263)(pp.1-69).TheWorldBank.Retrieved from http://documents.worldbank.org/curated/en/446761467991987706/ The-local-economic-impacts-of-resource-abundance-what-have-we-learned

Makivik Corporation. (2014). Nunavik mining policy. Retrieved from http://www. makivik.org/current/nunavik-mining-policies/

Rodon, T., \& Levesque, F. (2015). Understanding the social and economic impacts of mining development in Inuit communities: Experiences with past and present mines in Inuit Nunangat. The Northern Review, 41, 13-39. https://doi. org/10.22584/nr41.2015.002

Rodon, T., \& Schott, S. (2014). Towards a sustainable future for Nunavik. Polar Record, 50(03), 260-276. https://doi.org/10.1017/S0032247413000132

Rolfe, J., Gregg, D., Ivanova, G., Lawrence, R., \& Rynne, D. (2011). The economic contribution of the resources sector by regional areas in Queensland. Economic Analysis and Policy, 41(1), 15-36. https://doi.org/10.1016/S0313-5926(11)50002-5

Sandlos, J., \& Keeling, A. (2012). Claiming the new north: Development and colonialism at the Pine Point Mine, Northwest Territories, Canada. Environment and History, 18(1), 5-34. https://doi.org/10.3197/096734012X13225062753543

Swanson, L. A., \& Zhang, D. D. (2015). The base requirements, community, and regional levels of northern development. Northern Review, 38, 199-222. Retrieved from http://journals.sfu.ca/nr/index.php/nr/article/view/341

United Nations. Department of Economic and Social Affairs. (2007). Industrial development for the 21st century: Sustainable development perspectives. New York: United Nations.

Wilson, G. N., \& Alcantara, C. (2012). Mixing politics and business in the Canadian Arctic: Inuit corporate governance in Nunavik and the Inuvialuit Settlement Region. Canadian Journal of Political Science/Revue Canadienne de Science Politique, 45(4), 781-804. https://doi.org/10.1017/S0008423912000996

Zhang, D. D., \& Swanson, L. A. (2014). Toward sustainable development in the north: Exploring models of success in community-based entrepreneurship. Northern Review, 38, 113-132. Retrieved from http://journals.sfu.ca/nr/index. $\mathrm{php} / \mathrm{nr} /$ article/view/328 